\title{
Antibody therapy in Neurodegenerative Disease
}

\author{
Amber L Southwell ${ }^{1}$ and Paul H Patterson ${ }^{2}$ \\ ${ }^{1}$ Centre for Molecular Medicine and Therapeutics, Child and Family Research Institute, University of \\ British Columbia, BC, Canada; ${ }^{2}$ California Institute of Technology, Pasadena, CA, U.S.A.
}

\section{SYNOPSIS}

Advances in medical science have led to increased life expectancy and increased median age in the population. Because the symptoms of neurodegenerative diseases generally onset in mid- to late-life, a concomitant increase in the number of persons afflicted with these devastating diseases has occurred. Developing therapies for neurodegenerative diseases is of the highest priority due to the enormous cost of medical care required, as well as for the human suffering involved. Although caused by a variety of genetic and environmental insults, such diseases share commonalities. Many of these diseases are proteinopathies-diseases caused by misfolded, aggregating proteins. Antibodies that can recognize and remove misfolded proteins are ideally suited for proteinopathy therapeutics. The numerous intriguing advances in antibody-based therapies for neurodegenerative diseases are discussed in this review.

\section{KEY WORDS}

Alzheimer's disease, Parkinson's disease, Huntington's disease, immunotherapy, vaccination, immunization, intrabody

Accepted: May 28, 2010

Address for correspondence:

Paul H Patterson

1200 E California Blvd M/C 216-76

Pasadena, CA. 91125 , U.S.A.

Fax: 626-395-5805; e-mail: php@caltech.edu
IMMUNIZATION THERAPIES FOR ALZHEIMER'S DISEASE

\section{Preclinical experiments with $A \beta$ protein}

Alzheimer's disease (AD) affects some 26 million individuals worldwide, yet the currently available drugs treat only the symptoms. Thus, the need is urgent for the development of novel therapies. Moreover, such therapies should target the upstream events involved in causing the dementia that characterizes this disorder.

The primary diagnostic signs in postmortem $\mathrm{AD}$ brain are plaques that contain $\mathrm{A} \beta$ protein aggregates and neurofibrillary tangles (NFTs) that contain the hyperphosphorylated tau protein. Perhaps the most novel therapeutic strategy currently under study for $\mathrm{AD}$ is the use of antibodies (Abs) directed at either or both $A \beta$ and tau. Indeed, the results from preclinical work using this approach with various mouse $A D$ models have been so promising that at least 13 different $A \beta$ immunotherapy trials are currently in progress, enrolling an estimated $9,000 \mathrm{AD}$ patients worldwide $/ 40 /$.

This line of work began in 1996 with the finding by Solomon and colleagues that anti-A $\beta$ monoclonal $A b s$ can dissolve $A \beta$ aggregates in vitro and prevent $A \beta$ monomers from aggregating $169,70 /$. The finding that startled the field and brought $\mathrm{AD}$ immunotherapy to the fore was the dramatic result of immunizing the PDAPP AD mouse model, which as it ages develops plaques and memory deficits, with pre-aggregated $A \beta_{1-42}$. This treatment prevented plaque deposition and reduced the number of existing plaques, total $A \beta$ load, and gliosis 165/. Many groups have since extended these findings to a number of other mouse $\mathrm{AD}$ models and shown that behavioral deficits, including learning and memory, can be prevented by active immunization with various 
types of $A \beta$ immunogens and adjuvants. The ability of such active immunization protocols to reverse established neuropathology and behavioral deficits has been variable, however $/ 40 /$.

Given that animals are heterogeneous in the ability to mount a strong immune response, a logical alternative to the active immunization method is the passive approach, wherein purified anti-A $\beta$ polyclonal or monoclonal $A b s$ are injected. In fact, studies have shown that passive Abs immunotherapy is effective in reducing established plaque and $A \beta$ levels, neuritic dystrophy, behavioral deficits and, in one case, reduced aggregation of phosphorylated tau. The latter observation, among others, suggested that tau pathology is downstream of $A \beta$ pathology $/ 52 /$.

\section{Clinical trials with $\mathbf{A} \boldsymbol{\beta}$}

The remarkable results with the transgenic $A \beta$ mouse models led immediately to several early human trials. Despite the worry that anti-A $\beta$ Abs might cause autoimmune problems, in 1999 Elan and Wyeth $/ 20 /$ proceeded with a Phase I safety trial of 80 patients using the AN1792 vaccine consisting of a synthetic $A \beta_{1-42}$ peptide and the QS21 saponin adjuvant. Eighty mild to moderate $A D$ patients received 4 intramuscular injections of peptide + adjuvant, peptide alone, adjuvant alone, or placebo over 6 months. No serious adverse events were reported. In 2001, a Phase IIa 15month double-blind, placebo-controlled trial followed involving 372 mild to moderate $\mathrm{AD}$ patients. This trial was stopped in 2002 after $6 \%$ of the patients developed aseptic meningoencephalitis and leukoencephalopathy. The AN1792 + adjuvant approach was designed to accentuate a cellmediated immune response, which is appropriate for the elderly who often have a reduced immune response. Thus, it may be that the patients developing serious clinical side effects produced $\mathrm{A} \beta$-reactive autoimmune $\mathrm{T}$ cells.

Fortunately, some data are available on the efficacy of this immunotherapy trial that was halted prematurely. In a subgroup of the 30 Phase II patients at one center, improvements in some cognitive tests were seen in the 6 patients that exhibited the highest $A b$ titers $/ 26 /$. In a follow-up study 4.6 years later, another subset of vaccinetreated patients displayed a much-reduced rate of functional decline on the Dependence Scale and the Disability Assessment for Dementia Scale /78/. On the other hand, a volumetric MRI study showed that, compared with the controls, the Ab responders displayed increased loss of brain volume and increased ventricular enlargement. These anatomical changes did not, however, correspond with the enhanced Neuropsychological Test Battery scores that the antibody responders achieved over the controls $120 \%$. Although these seemingly contradictory findings remain to be explained, the cognitive testing results are encouraging, although certainly not as dramatic as those obtained in the mouse studies.

In terms of neuropathology, eight patient brains from the Phase I trial have been analyzed and showed a reduction in $A \beta$ load, with $2.1 \%$ of the area of the neuropil covered by amyloid staining in the AN1792 group compared with $5.1 \%$ in the control group, a difference that reached significance $127 \%$. Despite their lower plaque levels, however, all eight vaccinated patients displayed severe dementia at the time of death. This result is consistent with previous $\mathrm{AD}$ findings showing little correspondence between plaque load and dementia. In fact, individuals with normal cognition for their age group can exhibit significant plaque loads $/ 5 /$. Such findings highlight the need for a better identification of the potential drivers of neurotoxicity, the $A \beta$ oligomers, which can be stained by specific Abs $122 \%$. Yet another provocative finding from 9 patients who died between 4 months and 5 years after their first immunization is the observation that 15 times as many cerebral blood vessels were coated with $A \beta$ than controls. These patients also had a higher density of cortical microhemorrhages and microvascular lesions than did unimmunized controls. Unlike most of the immunized patients, however, two of the longest survivors had a virtually complete absence of plaques as well as cerebral amyloid angiopathy $17 \%$. The authors optimistically interpreted these findings as suggesting that the injected Abs mobilize $A \beta$ from the plaques, which then exits the brain via the cerebral vasculature, causing a transient increase in cerebral amyloid angiopathy. 
At least seven more trials of passive immunotherapies for mild to moderate $A D$ are underway. The results from a trial of a humanized monoclonal $\mathrm{Ab}$ (bapineuzimab, AAB-001) that binds the Nterminus of $A \beta$ indicated that the trial did not meet its endpoints for cognitive efficacy. A post hoc analysis, however, unadjusted for multiple comparisons found significant cognitive benefits $(\mathrm{p}<.05)$ in those $A D$ patients who did not carry the apolipoprotein E (APOE) e4 allele /64/. As this allele is a major risk factor for $\mathrm{AD}$, the results suggest that the potentially more severe pathogenesis in the carriers could not be overcome by the immunotherapy. Given the lack of dramatic effects, however, this trial did not have the power to determine if this monoclonal $\mathrm{Ab}$ had real cognitive benefits. The possible effect of the APOE allele is an important tip for future trials. Current Phase III bapineuzimab trials have enrolled 4,000 patients.

Another humanized monoclonal antibody, solanezumab (LY2062430) that binds the middle of $A \beta$ met safety standards in 52 patients, but cognitive scores were not affected. Increased levels of several forms of $A \beta$ were detected at high levels in sera, however, consistent with the mobilization of these peptides. Two large Phase III studies are underway, enrolling 2,000 patients. Several new trials are also underway using a modified active immunization approach $/ 40 /$.

\section{Experiments with IVIg antibodies}

An alternative immunotherapy involves intravenous immunoglobulin (IVIg). This approach has the advantage that the U.S. Food and Drug Administration has approved such injections as safe for several immune and inflammatory diseases. The Ig preparation is manufactured from the plasma of healthy subjects. This pooled mixture contains anti- $A \beta$ antibodies that can block the formation of $A \beta$ oligomers and fibrils, enhance the clearance of $A \beta$ from the brain, and protect neurons from $A \beta$ toxicity in culture $/ 40 /$. Moreover, in a pilot study, IVIg treatment stabilized cognitive loss in five AD patients /14/. In another study of $8 \mathrm{AD}$ patients, IVIg was administered for 6 months, stopped for 3 months, and then resumed for 9 months. The treated patients displayed improvement in mini-mental state examination scores at 6 months, declined during the washout, and then stabilized for the final 9 months $/ 60 /$. In addition, anti-A $\beta$ Abs were found in the CSF, suggesting that they can cross the BBB. Several further studies of IVIg therapy are now in progress.

In addition to the clinical trials, a retrospective case-control analysis examined the incidence of $\mathrm{AD}$ and related disorders in people $>65$ years old who had received IVIg for other indications. Five years after the start of the analysis, this group had a $42 \%$ lower risk of AD diagnosis /19/. Thus, both epidemiologic and early clinical findings with IVIg are encouraging, despite the fact that the anti-A $\beta$ Abs in the preparation are only a minor component of the mixture, and they have not been optimized for efficacy.

\section{Anti-tau immunotherapy}

The second major hallmark of $\mathrm{AD}$, the NFTs containing hyper-phosphorylated tau, has only recently begun to receive significant attention as an immunotherapeutic target. According to the amyloid hypothesis of $A D$, tau pathology is downstream of misfolded $A \beta$, although a dual pathway hypothesis has also received support /68/. In fact, mutations in tau can cause frontotemporal dementia with parkisonsim (FTDP) in the absence of amyloid plaques, and NFTs are better correlated with dementia in late onset $\mathrm{AD}$ than are plaques. Moreover, in one AD mouse model, anti-A $\beta$ immunotherapy cleared NFTs but not hyperphosphorylated tau aggregates $/ 52 /$, which has also been seen in human studies.

The first anti-tau immunotherapy results used a mouse model expressing a FTDP tau mutation $/ 3 /$. Immunization with a tau peptide containing two phosphorylated serines associated with NFTs resulted in the reduction of insoluble tau and an increase in soluble tau. Motor performance on the balance beam and rotarod was improved in the immunized group, but cognitive tests were not informative. Tagged Abs were detected in the brains of transgenic but not wild type mice, indicating that the Abs can cross the $\mathrm{BBB}$ in this model. It will be important to test this therapy in a true mouse model of $\mathrm{AD}$. As in the $\mathrm{A} \beta$ experiments, 
the choice of the tau preparation used as antigen can be critical, as certain immunogens can cause pathology in normal mice /63/. A focus on the toxic tau oligomers may prove to be the most productive approach, as may be true for $A \beta$ immunization $/ 32 /$.

\section{IMMUNIZATION THERAPIES FOR PARKINSON'S DISEASE}

Among the mutations that can cause Parkinson's disease (PD), those that have received the most attention are in the protein $\alpha$-synuclein. This protein is also found in the Lewy body inclusions that are characteristic of the idiopathic, non-familial form of the disease. Contemplating immunization approaches targeting $\alpha$-synuclein may appear at first to be misguided, as this protein is thought to be intracellular, localized primarily in presynaptic terminals. The evidence shows that under pathological conditions, however, $\alpha$-synuclein oligomers and protofibrils are detectable on the plasma membrane $/ 13,15,38 /$. Moreover, a series of recent studies has demonstrated that a mutant $\alpha$ synuclein protein can be transferred from cell to cell, spreading the disease in the brain in a prionlike (but non-infectious) manner $/ 1 /$. Thus, circulating Abs may have access to $\alpha$-synuclein.

The major immunotherapy work published thus far has employed active immunization with human $\alpha$-synuclein for 8 months in a mouse model over-expressing human $\alpha$-synuclein $146 /$. This model displays motor deficits and signs of synaptic degeneration that were attenuated by immunization. The levels of aggregated human $\alpha$-synuclein were also diminished, and the effects correlated with the relative affinity of the Abs generated in the mice. The injection of tagged, purified monoclonal, antihuman $\alpha$-synuclein Abs resulted in binding to cell bodies and synapses in $\alpha$-synuclein-expressing but not in wild type mice. Cathepsin D was upregulated in the labeled neurons, suggesting that the circulating Abs can recognize the aggregated $\alpha$-synuclein and cause its clearance via lysosomal activation $/ 46 /$.

In a different type of passive immunotherapy approach, adoptive transfer, immune cells that cross-react with myelin basic protein (MBP) were injected in the MPTP mouse model of PD /6/. The cells were generated by stimulating donor mice with copolymer-1 (Cop-1; Copaxone, glatiramer acetate) $/ 75 /$, a random amino acid polymer that protects against brain injury without the encephalitis associated with MBP immunization. The rationale for the use of these immune cells in the PD model is that Cop-1 stimulates TH2 cells, a $T$-cell subset that secretes anti-inflammatory cytokines, as inflammation is part of the toxic neuropathology in $\mathrm{PD} 123 /$. The intravenous administration of Cop-1-stimulated spleen cells to MPTP-treated mice suppressed microglial activation and protected dopaminergic neurons. This reaction could be a direct effect of the immune cells as the injected cells were found in inflamed brain regions 16/. Depletion of the donor $T$ cells abrogated the beneficial effects, indicating that this type of cell was responsible for the therapeutic benefit. Furthermore, the injection of regulatory $\mathrm{T}$ (Treg) cells, which can control the level of inflammation, protects against MPTP-induced dopaminergic neurodegeneration $/ 61 /$, which is contradictory to a theory of protective autoimmunity $/ 66 /$.

Just as sera from healthy individuals contain anti-A $\beta$ auto-Abs, such sera also contain anti- $\alpha$ synuclein Abs. Whereas $31 \%$ of control sera contain anti- $\alpha$-synuclein $\mathrm{Abs}, 90 \%$ and $52 \%$ of sera from familial and sporadic PD patients, respectively, contain such Abs 154/. Because endogenous anti- $\alpha$-synuclein $A b s$ can be toxic or beneficial, their physiological effects must be determined.

\section{IMMUNIZATION THERAPIES FOR HUNTINGTON'S DISEASE}

Huntington's disease (HD) is an autosomal dominant, neurodegenerative disease resulting from the expansion of a normally occurring glutamine repeat in exon 1 of the huntingtin protein $(\mathrm{Htt})$. When this expansion is greater than 36 , the protein misfolds and accumulates as aggregates $/ 11,28 /$. The mutant $\mathrm{Htt}$ protein $(\mathrm{mHtt})$ is deficient in performing vital functions of the wildtype $\mathrm{Htt}$ (wtHtt), including mediating axonal transport, transcriptional regulation, and mitochondrial metabolism. In addition, $\mathrm{mHtt}$ also engages in aberrant interactions, such as 
sequestering important cellular proteins, including transcription factors and vesicle-associated proteins $/ 29 /$. These interactions lead to striatal and cortical atrophy as well as to motor and cognitive decline $/ 50 \%$. Despite the simple genetic nature of $\mathrm{HD}$, available therapies are aimed at symptom management rather than disease modification. Recent work has shown, however, that Ab-based therapeutic approaches can be developed against the most upstream target in $\mathrm{HD}$, the $\mathrm{mHtt}$ protein itself. Such approaches have the potential to prevent the onset or delay the progression of HD.

The intracellular localization of the $\mathrm{mHtt}$ protein makes it a less than ideal target for immunization therapies. Nonetheless, systemic vaccination with DNA for an N-terminal fragment of $\mathrm{mHtt}$ ameliorates the diabetic phenotype of the R6/2 transgenic mouse model of $\mathrm{HD}$ and normalizes pancreatic insulin levels $/ 47 /$. This effect is reminiscent of the positive effects of peripheral injection of the cytoplasmic protein $\alpha$-synuclein discussed above. The immunized mice, however, displayed highly variable serum responsiveness; no clear effects on brain pathology or behavior were observed, limiting the therapeutic potential of this approach.

\section{Intrabody therapy}

Intrabodies (iAbs), intracellularly expressed antibody fragments consisting only of antigen recognition domain(s), are a powerful potential therapeutic for proteinopathies, including $A D, P D$, and $\mathrm{HD}$. These highly specific reagents can be developed to recognize an infinite number of targets, including amino acid sequence, protein conformation, post-translational modifications, and specific protein interactions. In addition, trafficking sequences can be used to target iAbs to specific sub-celiular compartments /44/. A number of therapeutic iAbs recognizing either distinct conformations or distinct epitopes in proteins that cause neurodegenerative diseases have been developed.

\section{Conformation-specific intrabody therapies}

Each of the mutated proteins discussed here can adopt a number of conformations, including monomers, oligomers, protofibrils, and the fibrillar structures found in $A \beta$ plaques, Lewy bodies, and large $\mathrm{mHtt}$ aggregates (Figure 1). Although some conformations confer toxicity, others perform the beneficial functions of these proteins. Amyloid precursor protein, which gives rise to $A \beta$, .. is involved in normal neuronal physiology, and perturbations could lead to unknown consequences. The $\alpha$-synuclein protein is natively unfolded and although the oligomeric form is cytotoxic, the monomeric form performs vital beneficial functions. The $\mathrm{mHtt}$ protein is also a dynamic protein forming multiple structures. Targeting specific conformations of these disease-causing proteins with iAbs should allow therapeutic intervention with minimal disruption of normal function. Of note, a number of Abs have been isolated that bind well to oligomeric or fibrillar species of several different toxic proteins that do not share amino acid sequence homology 18,31 . Thus, these Abs apparently bind to a conformation shared by the amino acid backbone of several proteins, without regard to the diversity in amino acid side chains.

$\mathrm{D} 5$ is an $\mathrm{iAb}$ raised from a phage display library against oligomeric $\alpha$-synuclein. This $\mathrm{iAb}$ reduces in vitro aggregation and extracellular toxicity of $\alpha$-synuclein in neuroblastoma cells $/ 16 /$. When fused to a secretion signal (D5-SEC), this $\mathrm{iAb}$ causes the removal of intracellular $\alpha$-synuclein, which in turn reduces the toxicity of overexpresssed $\alpha$-synuclein in co-transfected 293 cells /81/. D5 also recognizes an oligomeric form of $\mathrm{mHtt}$. Although it reduces aggregation of $\mathrm{mHtt}$ in vitro, D5 binding increases toxicity in a cell culture model of $\mathrm{HD} / 51 /$. Another $\mathrm{iAb}$, syn-10H, recognizes a stage of $\alpha$-synuclein oligomer that is larger and later than D5. This $\mathrm{iAb}$ recognizes aggregates in PD but not in normal human brain and reduces $\alpha$-synuclein-induced toxicity in neuroblastoma cells /17/.

$6 \mathrm{E}$ is an iAb selected for binding to fibrillar $\alpha$-synuclein but also recognizes only the fibrillar form of $\mathrm{mHtt}$. This $\mathrm{iAb}$ increases fibril formation, aggregation, and toxicity of $\mathrm{mHtt}$ in a cell culture model of $\mathrm{HD} / 36 /$. The extreme selectivity of conformation-specific iAbs that allow differentiation, not only between mutant and wt proteins but also between various species of mutant proteins, 


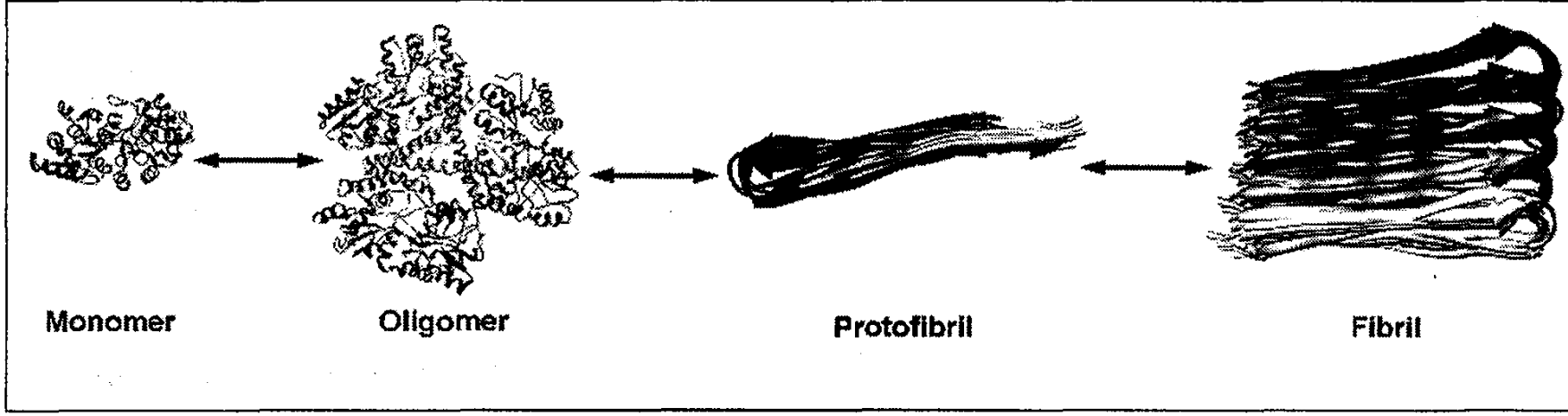

Fig. 1: Aggregating proteins adopt multiple conformations. Despite differences in size, sequence and function, the proteins that cause $\mathrm{AD}, \mathrm{PD}$ and $\mathrm{HD}$ adopt similar structures including soluble monomers, small aggregated oliogomers, $\beta$-sheet organized protofibrils, and large aggregated cross- $\beta$-sheet amyloid fibrils. Molecular graphics were made using UCSF's Chimera /57/ based on protein data bank entries 3IO4 and 2BEG.

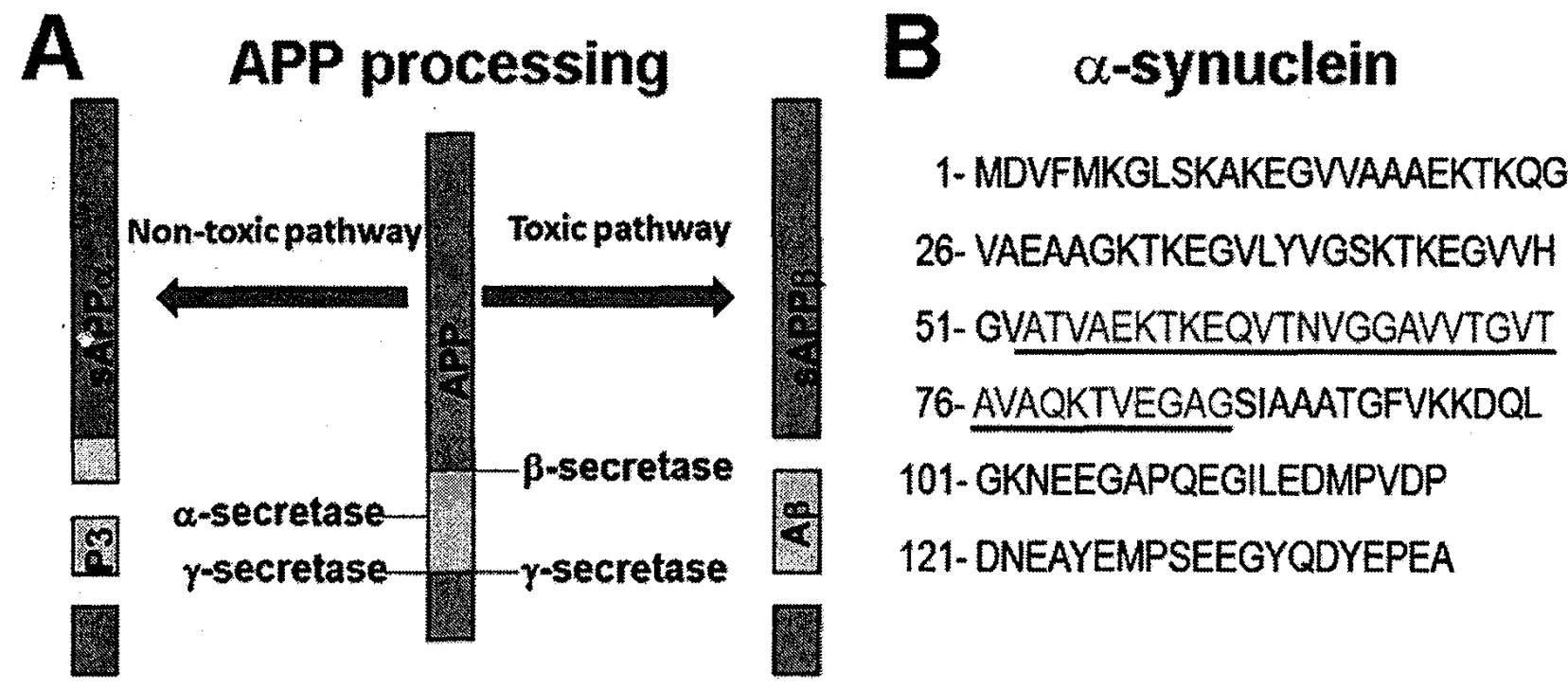

\section{Huntingtin exon 1}

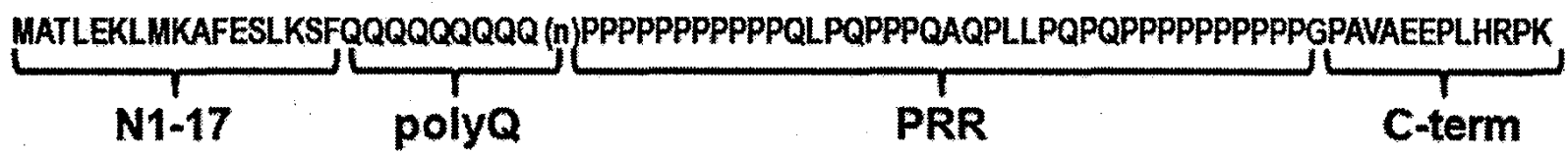

Fig. 2: Sequences and diagrams of several proteins that cause neurodegenerative disease. (A) Divergent proteolytic processing of APP leads either to production of the non-toxic P3 peptide or to the production of the pathogenic $\mathrm{A} \beta$ peptide that accumulates in AD brain. (B) $\alpha$-synuclein is the major protein component of the Lewy bodies characteristic of $\mathrm{PD}$. The non-amyloid component (NAC) shown underlined is also found in the A $\beta$ plaques of AD. (C) Exon 1 of the Htt protein, the site of the mutation that causes HD. PRR, proline rich region. 
warrants further investigation in both structural and therapeutic contexts.

\section{EPITOPE-SPECIFIC INTRABODY THERAPIES FOR ALZHEIMER'S DISEASE}

As discussed above, the major component of plaques in $\mathrm{AD}$ brains is $\mathrm{A} \beta$, one of the products generated from the proteolytic processing of the amyloid precursor protein (APP). APP is processed by one of two mutually exclusive cleavage pathways. In the first, more common pathway, APP is cleaved by $\alpha$-secretase generating the non-toxic P3 fragment. In the second much less common pathway, APP is cleaved by $\beta$-secretase generating $A \beta$ (Figure $2 A$ ) $/ 25 /$. The two common forms of $A \beta$, are the $40 \mathrm{AA}$ form, $A \beta_{40}$, and the $42 \mathrm{AA}$ form, $A \beta_{42}$. The longer form, $A \beta_{42}$, is less soluble and has a greater propensity to form oligomers and fibrils, leading to enhanced toxicity $/ 37 /$.

As the differential proteolytic processing of APP can lead to either toxic or non-toxic products, emulating or enhancing the $\alpha$-secretase cleavage of APP has therapeutic potential. A screen of iAbs for $\alpha$-secretase-like activity identified two iAbs with possible therapeutic applications for $\mathrm{AD}$. A serineprotease-like iAb, c23.5, mimics $\alpha$-secretase cleavage, producing the 1-16 and 17-40 amino acid fragments of $A \beta$. A carboxypeptidase-like $i A b$, $h k 14$, sequentially cleaves the C-terminal residues of $A \beta_{42}$, generating the less toxic $A \beta_{40} / 59 /$. Another $\mathrm{iAb}, \mathrm{sFv} \beta 1$, recognizes an epitope adjacent to the $\alpha$ secretase site of APP at AA 3-6 of A $\beta$. This $i A b$ shifts APP processing toward the more favorable $\alpha$ secretase product, reducing $A \beta$ production and toxicity in co-transfected 293 cells. When fused to an endoplasmic reticulum (ER) retention signal, sFv $\beta 1$ prevents the newly generated APP from leaving the $\mathrm{ER}$, leading to its degradation and virtually abolishing $A \beta$ production $/ 53 /$.

Other iAbs have been selected from phage display libraries for $A \beta$-binding efficacy. $H 1$ v2 is an $i A b$ that recognizes $A A$ 17-28 of $A \beta$ and reduces its in vitro aggregation. The co-incubation of this $\mathrm{iAb}$ with $\mathrm{A} \beta$ prevents extracellular toxicity to neuroblastoma cells $/ 43 /$. The adeno-associated virus (AAV)-mediated delivery of anti-A $\beta$ iAb scFv59 to the cortico-hippocampal region of the brains of $\mathrm{Tg} 2576 \mathrm{AD}$ model mice results in strong $\mathrm{iAb}$ expression and reduced $\mathrm{A} \beta$ plaque load as long as 1 year post-injection $/ 21 /$.

Immunization studies have identified monoclonal Abs that when passively delivered, prevent $\mathrm{A} \beta$ plaque deposition in the brains of $\mathrm{AD}$ transgenic mice. Three iAbs have been generated from such Abs; scFv9, which recognizes AA 1-16 and binds both $A \beta 40$ and $A \beta 42$, and scFv40.1 and $\mathrm{scFv} 42.2$, which respectively recognize $A \beta 40$ and $\mathrm{A} \beta 42,142 \%$. An AAV-mediated delivery of any of these iAbs to the ventricles of P0 CRND8 AD model mice resulted in a $25 \%$ to $50 \%$ reduction in A $\beta$ plaque deposition $/ 41 /$. The beneficial effects of scFv42.2 were enhanced by the addition of an ER retention signal. The AAV-mediated delivery of the modified iAb to the hippocampus of $3 \times T g$ $A D$ model mice resulted in not only reduced $A \beta 42$ plaque load but also reduced levels of hyperphosphorylated tau, once again indicating that tau pathology is downstream of the $A \beta$ pathology in $\mathrm{AD} / 74 /$.

\section{EPITOPE-SPECIFIC INTRABODY THERAPIES FOR PARKINSON'S DISEASE}

The primary component of the Lewy body inclusions that characterize PD is $\alpha$-synuclein, and a portion of this protein, the non-amyloid component (NAC), is found in $\mathrm{AD}$ plaques (Figure 2B). Although far less common than sporadic PD, familial PD is most often caused by mutations in the $\alpha$-synuclein gene. Moreover, the overexpression of wt $\alpha$-synuclein is sufficient to cause a PD-like toxicity in cells, flies, and mice /12/. For these reasons, $\alpha$-synuclein is the primary therapeutic iAb target for PD.

$\mathrm{NAC} 32$ is an iAb selected from a phagedisplay library against the NAC of $\alpha$-synuclein. NAC32 expression reduces the aggregation and toxicity of a mutant form of $\alpha$-synuclein in cotransfected ST14A cells $/ 45 /$. Another iAb selected from a phage display library is D10, which recognizes monomeric $\alpha$-synuclein. D10 expression reduces the aggregation and toxicity of overexpressed wt $\alpha$-synuclein in co-transfected 293 cells. When fused to a nuclear localization signal (NLS), this iAb re-targets $\alpha$-synuclein to the 
nucleus, but has no effect on the localization of the highly homologous $\alpha$-synuclein, demonstrating the extreme specificity of iAbs /82/. The beneficial effects on toxicity are augmented when D10 is fused to a secretion signal (D10-SEC), leading to the removal of $\alpha$-synuclein from cells $/ 81 /$. Interestingly D10-SEC leads to the removal of larger quantities of $\alpha$-synuclein than the oligomerspecific D5-SEC, but is not as beneficial, indicating lower cellular levels of the more toxic oligomeric species.

\section{EPITOPE-SPECIFIC INTRABODY THERAPIES FOR HUNTINGTON'S DISEASE}

Exon 1 of $\mathrm{Htt}(\mathrm{HDx}-1)$, the site of the mutation that cavses $H D$, consists of $17 \mathrm{~N}$-terminal amino acids, a polyglutamine (polyQ) tract, the proline rich region (PRR) that includes two polyproline (polyp) tracts separated by a proline rich (P-rich) sequence, and $13 \mathrm{C}$-terminal amino acids (Fig. $2 \mathrm{C})$. Potential therapeutic iAbs recognizing each of the four regions of HDx-1 have been developed.

\section{Intrabodies recognizing N1-17}

The N-terminus of Htt is the site of many important interactions including membrane association and post-translational modifications $/ 4$, 62/. This domain regulates the localization, aggregation and degradation of $\mathrm{Htt} / 76,77 /$. Two iAbs recognizing this region, $C 4$ and $V_{L} 12.3$, have been developed as potential therapeutics.

$\mathrm{C} 4$ is an iAb isolated from a phage-display library that preferentially binds to diffuse but not to aggregated $\mathrm{N}$-terminal $\mathrm{Htt}$ fragments $148 /$. The expression of this $\mathrm{iAb}$ in 293 and ST14A cells reduces the level of both wt and aggregated $\mathrm{mHtt}$, but increases the level of soluble $\mathrm{mHtt} / 48 /$. The $\mathrm{C} 4 \mathrm{iAb}$ was originally shown to reduce the aggregation and toxicity of $\mathrm{mHtt}$ in cell culture models of $\mathrm{HD}$, but it required a 5:1 ratio to $\mathrm{mHDx}$ 1 for optimal effects $/ 39 /$. Re-engineering C4, which involved mutagenizing and selecting for greater Htt binding affinity, resulted in an $\mathrm{iAb}$ that protects against malonate-induced toxicity in mHDx-1-transfected organotypic slice cultures 149/. In a Drosophila model of $\mathrm{HD}$, the $\mathrm{C} 4 \mathrm{iAb}$ also rescues the eclosion deficit, increases adult survival, and decreases photoreceptor degeneration 180\%.

$\mathrm{V}_{\mathrm{L}} 12.3$ is a single domain, light chain $\mathrm{iAb}$ selected from a yeast surface display library that reduces $\mathrm{mHDx}-1$ aggregation in a cell-free system as well as in mHtt co-transfected 293 cells /9/. Although originally requiring a $5: 1$ ratio to $\mathrm{mHDx}-1$ for optimum effects, the $V_{L} 12.3$ iAb was reengineered by removal of the disulfide bond, random mutagenesis and selection for greater $\mathrm{Htt}$ binding affinity, yielding a very stable, soluble and potent $\mathrm{iAb} / 10 /$. The mature $\mathrm{V}_{\mathrm{L}} 12.3 \mathrm{iAb}$ reduces $\mathrm{mHDx}-1$ - induced toxicity and aggregation at low iAb:HDx-1 ratios in both cell culture and organotypic slice culture models of $\mathrm{HD}$. Consistent with the cytoplasmic retention function of the $\mathrm{Htt}$ $\mathrm{N}$-terminus, $\mathrm{V}_{\mathrm{L}} 12.3$ binding also causes an increase in nuclear $\mathrm{HDx}-1$ /71/. The $\mathrm{V}_{\mathrm{L}} 12.3 \mathrm{iAb}$ was also tested in vivo in a variety of mouse models of $\mathrm{HD}$. In one model involving the lentiviral delivery of $\mathrm{mHDx}-1$ to the striatum of 4week-old wt mice, the AAV-mediated striatal delivery of $\mathrm{V}_{\mathrm{L}} 12.3$ dramatically reduces $\mathrm{mHtt}$ aggregation and striatal neuron death and rescues the abnormal amphetamine-induced rotation phenotype of these mice. Despite such promising results in acute cellular and in vivo models of $\mathrm{HD}$, the AAV- $V_{L} 12.3$ treatment of $R 6 / 2$ and transgenic models of $\mathrm{HD}$ results in no change or even a worsening of phenotypic severity, including decreased survival of $\mathrm{R} 6 / 2$ mice despite a dramatic reduction in striatal $\mathrm{HDx}-1$ aggregates $/ 72 /$.

The target of C4 and VL12.3, the N-terminus of $\mathrm{Htt}$, is required for cytoplasmic retention. Compromising the cytoplasmic retention this function of the $\mathrm{Htt} \mathrm{N}$-terminus results in increased nuclear $\mathrm{Htt}$ that is associated with increased toxicity $156,62 /$. The $\mathrm{N}$-terminus domain is also required for aggregate seeding, which may be a protective mechanism $/ 2,67,7576 /$. The $\mathrm{N}$-terminus is also the site of several important posttranslational modifications, including phosphorylation, which increases the degradation of $\mathrm{mHtt}$ and is neuro-protective $124,76,77 /$. For these reasons, the iAb blockade of the N-terminus of $\mathrm{Htt}$ may not be an ideal long-term therapeutic strategy for HD, as suggested by in vivo results with VL12.3. 


\section{Intrabodies recognizing polyQ}

The expanded polyQ tract is the only AA sequence difference between wt and $\mathrm{mHtt}$, and as the polyQ tract alone can confer toxicity, this epitope should be an ideal target for iAb therapy directed selectively at $\mathrm{mHtt}$.

MW1 and MW2 are iAbs derived from monoclonal antibodies that recognize polyQ in $\mathrm{HDx}-1$. The iAbs preferentially bind $\mathrm{mHDx}-1$ and $\mathrm{mHtt}$ and recognize both the native and denatured proteins. Despite the ability of the expanded polyQ domain to confer toxicity, the treatment of cell culture and organotypic brain slice models of $\mathrm{HD}$ with MW1 or MW2 increases $m H D x-1$-induced toxicity and aggregation $/ 33 \%$. This increase in toxicity could potentially be the result of an iAbmediated stabilization of a toxic conformation of mHDx-1 or an iAb-mediated cross-linking of mHDx-1 molecules, which could accelerate oligomer formation. An exploration of such possible mechanisms may shed light on the molecular basis of mHtt toxicity. Despite the potential selectivity of targeting this domain, the results indicate that $\mathrm{iAb}$ binding to the polyQ tract is more likely to potentiate than to ameliorate toxicity.

\section{Intrabodies recognizing the proline rich region}

The PRR of mHtt mediates a number of aberrant protein-protein interactions, including the sequestration of $\mathrm{SH} 3$ and WW domain-containing transcription factors and vesicle proteins $/ 18,58 /$. These domains are the site of interactions with IKK $\gamma$, a regulatory subunit of the I $\mathrm{KB}$ kinase complex. Activating this complex promotes aggregation and nuclear localization of $\mathrm{mHtt} / 34 /$. The PRR of Htt is also the site of its interactions with P53 and the CREB-binding protein and the $\mathrm{PRR}$ is required for mHtt-induced transcriptional repression of P53-regulated genes /73/. All these toxic interactions are strengthened in response to increased polyQ length. Three iAbs recognizing the PRR domain, MW7, Happl and Happ3, have been developed as possible HD therapeutics.

MW7 is an iAb derived from a monoclonal antibody that recognizes polyP. This $\mathrm{iAb}$ reduces mHDx-1-induced toxicity and aggregation in cell culture, Drosophila, and organotypic brain slice models of $\mathrm{HD} / 30,33,71 /$. MW7 binding results in an increased clearance of soluble mutant but not wtHDx-1, a mechanism with great therapeutic potential /71/. The MW7 iAb is, however, not very potent as it requires a $4: 1$ ratio to $m H D x-1$ for optimal effects 133\%. Although no evidence of MW7 binding to proteins other than $\mathrm{Htt}$ has been observed, the specificity of this $\mathrm{iAb}$ for pure polyP could potentially allow binding to other polyP domain-containing proteins.

Happ1 and Happ3 are single domain $V_{L}$ iAbs selected from a phage-display library that recognize the P-rich domain of Htt lying between the two polyP tracts (Fig. 2C). These iAbs have the beneficial properties of $M W 7$, including the reduction of $\mathrm{mHtt}$-induced aggregation and toxicity in cell culture and organotypic brain slice models of $\mathrm{HD}$, as well as an increased clearance of $\mathrm{mHtt}$. Moreover, the recognition of a single, unique sequence found only in $\mathrm{Htt}$ increases the likelihood of extreme binding specificity. In addition, Happ 1 and 3 display increased potency over MW7, requiring a $2: 1$ ratio to $\mathrm{mHtt}$ for optimum effects $/ 71 /$. Although these iAbs bind to both mutant and wtHDx-1 in denaturing conditions, the selectivity for the increased clearance of only the mutant protein in cells in native conditions indicates a strong preference for this form. This preference may be due to the increased availability of the PRR epitope in expanded polyQ $\mathrm{Htt}$ conformations. This idea is supported by the findings of increased binding of other Htt PRRinteracting partners with increased polyQ length $155,58,73 /$.

The results obtained with five different $H D$ mouse models further support the therapeutic utility of Happ1 /72/. AAV-mediated intrastriatal delivery of this $\mathrm{iAb}$ in the lentiviral mouse model dramatically reduces $\mathrm{mHDx}-1$ aggregation and striatal neuron death and completely rescues the amphetamine-induced rotation behavioral phenoltype. In addition, delivery of AAV-Happ1 to the striatum of the R6/2, N171-82Q, YAC128, and $\mathrm{BACHD}$ transgenic $\mathrm{HD}$ models ameliorates many aspects of the HD-like phenotype. Normal motor performance is restored in N171-82Q, YAC128, and $\mathrm{BACHD}$ mice, and motor performance is improved in $\mathrm{R} 6 / 2$ mice. The cognitive effects of $\mathrm{mHtt}$ are another important aspect of $\mathrm{HD}$, and 


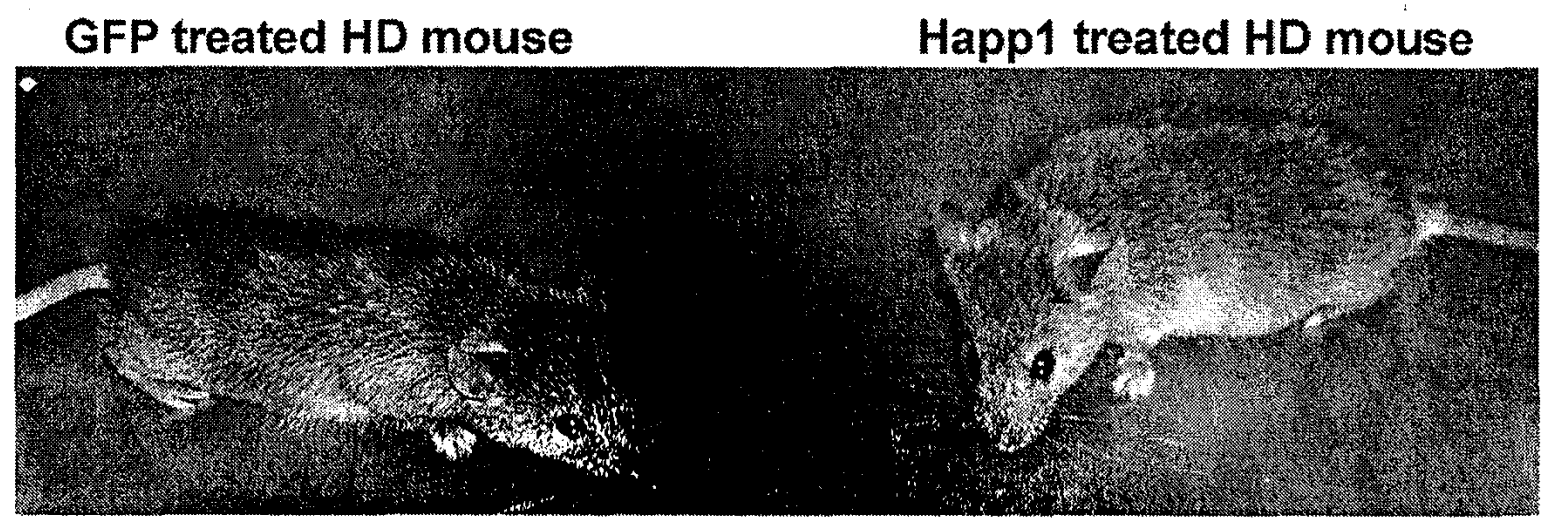

Fig. 3: Happ1 treatment improves body weight of N171-82Q HD model mice. The GFP-treated N171-82Q mouse (left) aisplays reduced body weight, crouched posture and ruffled coat, whereas the Happ 1-treated N171-82Q mouse (right) displays normal body weight and appearance. The mice shown are male littermates. /72/

Happ1 treatment restores normal cognitive performance in $\mathrm{YAC} 128$ mice and improves cognitive performance in BACHD mice. Happl treatment also ameliorates neuropathology in these models. HDx-1 aggregation is strongly reduced in the $\mathrm{R} 6 / 2$ model, and ventricle size is normalized in $\mathrm{R} 6 / 2$, YAC128, and BACHD mice. Although Happ1 has no effect on $\mathrm{R} 6 / 2$, YAC128, or $\mathrm{BACH}$ body weight or $\mathrm{R} 6 / 2$ survival, this $\mathrm{iAb}$ does significantly increase both body weight and life span of N171-82Q mice (Figure. 3) /72/. Engineering to increase stability and binding affinity could potentially further improve this very promising $\mathrm{iAb}$.

One potential mechanism that could mediate the positive effects of the anti-PRR iAbs could involve the blockade of a number of aberrant interactions of $\mathrm{mHtt}$ with other proteins that lead to a gain of toxic function. Another mechanism involves the regulation of $\mathrm{mHtt}$ stability because $\mathrm{iAb}$ binding to the PRR leads to increased clearance of the mutant but not the wildtype protein.

\section{Intrabodies recognizing the $\mathrm{C}$ terminus of $\mathrm{HDx}-1$}

Although the functions of the C-terminus of HDx-1 are unclear, results with two iAbs, EM48 and MW8, which bind this region, indicate that this domain contributes to $\mathrm{mHtt}$ toxicity.
EM48 is an iAb derived from a monoclonal antibody that recognizes an epitope in the Cterminus of $\mathrm{HDx}-1$ that is adjacent to the PRR. This iAb preferentially binds $\mathrm{mHDx}-1$ and increases its ubiquitination and turnover in a cell-culture model of HD. Adenoviral delivery of EM48 to the striatum of R6/2 and N171-82Q HD model mice reduces striatal neuropil aggregates, increases $\mathrm{Htt}$ cleavage products, and improves the motor performance of N171-82Q mice. Yet, EM48 gene therapy has no effect on intranuclear inclusions, body weight, or survival $/ 79 /$.

MW8 is an iAb derived from a monoclonal antibody that recognizes a unique epitope in the Cterminus of $\mathrm{HDx}-1$. This $\mathrm{iAb}$ preferentially binds aggregated rather than diffuse $\mathrm{Htt}$, allowing selectivity for the mutant form. MW8 treatment reduces $\mathrm{mHtt}$-induced toxicity and aggregation in cell culture models of HD, although its beneficial effects are modest in comparison to those of several other iAbs, making MW8 a poor choice for further development $/ 35 /$.

Taken together, these studies demonstrate that the $\mathrm{iAb}$ gene therapy strategy for the treatment of HD can be very effective. Those iAbs directed at the regions flanking the $\mathrm{HD}$ mutation rather than at the mutation itself, and particularly those that can distinguish between mutant and wtHtt, display the greatest promise. 


\section{PERSPECTIVES}

Clearly, a wide variety of antibody-based therapies can have striking efficacy in animal models of $\mathrm{AD}, \mathrm{PD}$, and $\mathrm{HD}$. Clinical testing of passive and active $A \beta$ immunization for $A D$ is quite advanced. Regrettably, the early safety results nave been somewhat mixed, and the early efficacy results have certainly not been as impressive as in the mouse models. Nonetheless, this therapy is still in its very early days, and one should recall the many missteps and the finetuning that was required to achieve the nearly uniform success we now enjoy with bone marrow, kidney, and heart transplant procedures. Many patients gave their lives in those clinical experiments, which has not yet been the case in the context of immunotherapy for $\mathrm{AD}, \mathrm{PD}$, and $\mathrm{HD}$. Indeed, more than fine-tuning must be done to test immunctherapy for neurodegenerative diseases. Clinical experiments are needed to sort out the relative efficacy of non-specific versus highly specific antibody approaches, systemic versus intracranial delivery, gene therapy versus active or passive immunization, and antibody versus intrabody approaches. Hopefully, the large clinical trials of immunization for AD now underway will yield enough positive results to sustain the momentum of the immunotherapy approach to these devastating diseases.

\section{ACKNOWLEDGMENTS}

Molecular graphics images were produced using the UCSF Chimera package from the Resource for Biocomputing, Visualization, and Informatics at the University of California, San Francisco (supported by NIH P41 RR-01081).

\section{REFERENCES}

1. Aguzzi A, Rajendran L. The cytosolic spread of amyloids, prions and prionoids. Neuron 2009;64: 783-90.

2. Arrasate M, Mitra S, Schweitzer ES, Segal MR, Finkbeiner S. Inclusion body formation reduces levels of mutant huntingtin and the risk of neuronal death. Nature 2004;431:805-810.
3. Asuni AA, Boutajangout A, Quartermain D, Sigurdsson EM. Immunotherapy targeting pathological tau conformers in a tangle mouse model reduces brain pathology with associated functional improvements. J Neurosci 2007; 27:9115-29.

4. Atwal RS, Xia J, Pinchev D, Taylor J, Epand RM, Truant R. Huntingtin has a membrane association signal that can modulate huntingtin aggregation, nuclear entry and toxicity. Hum Mol Genet 2007; 16:2600-15.

5. Ballatore C, Lee VM-Y, Trojanowski JQ. Taumediated neurodegeneration in Alzheimer's disease and related disorders. Nature Rev Neurosci 2007; 8:663.

6. Benner EJ, Mosely RL, Destache CJ, Lewis TB, Jackson-Lewis V, Gorantla S, Nemachek C, Green SR, Przedborski S, Gendelman HE. Therapeutic immunization protects dopaminergic neurons in a mouse model of Parkinson's disease. Proc Natl Acad Sci USA 2004; 101:9035-40.

7. Boche D, Zotova E, Weller RO, Love S, Neal JW, Pickering RM, Wilkinson D, Holmes C, Nicoll JAR. Consequence of $A \beta$ immunization on the vasculature of human Alzheimers disease brain. Brain 2008; 131:3299-10.

8. Chen S, Berthelier V, Hamilton JB, O'Nuallai B, Wetzel R. Amyloid-like features of polyglutamine aggregates and their assembly kinetics. Biochemistry 2002; 41:7391-9.

9. Colby DW, Garg P, Holden T, Chao G, Webster JM, Messer A, Ingram VM, Wittrup KD. Development of a human light chain variable domain (VL) Intracellular antibody specific for the amino terminus of huntingtin via yeast surface display. J Mol Bio 2004; 342:901-12.

10. Colby DW, Chu Y, Cassady JP, Duennwald $M$, Zazulak H, Webster JM, Messer A, Lindquist $S$, Ingram VM, Wittrup KD. Potent inhibition of huntingtin aggregation and cytotoxicity by a disulfide bond-free single-domain intracellular antibody. Proc Natl Acad Sci USA 2004; 101 : 7616-21.

11. Danny MH. Protcin misfolding inside cells: The case of huntingtin and Huntington's disease. IUBMB Life 2008; 60:724-8.

12. Dauer W, Przedborski S. Parkinson's disease: mechanisms and models. Neuron 2003;39:889909.

13. Dixon C, Mathias N, Zweig RM, Davis DA, Gross DS. Alpha synuclein targets the plasma membrane via the secretory pathway and induces toxicity in yeast. Genetics $2005 ; 170: 47-59$.

14. Dodel R, Hampel H, Depboylu C, Lin S, Gao F, 
Schock S, Jäckel S, Wei X, Buerger K, Höft C, Hemmer B, Möller HJ, Farlow M, Oertel WH, Sommer N, Du Y. Human antibodies against amyloid beta peptide: a potential treatment for Alzheimer's disease. Ann Neurol 2002; 52:253-6.

15. Eliezer D, Kutuay E, Bussell R, Browne G. Conformational properties of $\alpha$-synuclein in its free and lipid-associated states. J Mol Biol 2001;307:1061-73.

16. Emadi S, Barkhordarian H, Wang MS, Schulz P, Sierks MR. Isolation of a human single chain antibody fragment against oligomeric alphasynuclein that inhibits aggregation and prevents alpha-synuclein-induced toxicity. J Mol Biol 20J7; 368:1132-44.

17. Emadi S, Kasturirangan S, Wang MS, Schulz P, Sierks MR. Detecting morphologically distinct oligomeric forms of alpha-synuclein. J Biol Chem 2009; 284:11048-58.

18. Faber PW, Barnes GT, Srinidhi J, Chen J, Gusella $J F$, MacDonald ME. Huntingtin interacts with a family of WW domain proteins. Hum Mol Genet 1998; 7:1463-74.

19. Fillit H, Hess G, Hill J, Bonner P, Toso C. IV immunoglobulin is associated with a reduced risk of Alzheimer disease and related disorders. Neurol 2009; 73:180-5.

20. Fox NC, Black RS, Gilman S, Rossor MN, Griffith SG, Jenkins L, Koller M; AN1792(QS21)-201 Study. Effects of $A \beta$ immunization (AN1792) on MRI measures of cerebral volume in Alzheimer disease. Neurol 2005; 64:1563-72.

21. Fukuchi K-i, Tahara K, Kim H-D, Maxwell JA, Lewis TL, Accavitti-Loper MA, Kim H, Ponnazhagan $S$, Lalonde $R$. Anti-A $\beta$ single-chain antibody delivery via adeno-associated virus for treatment of Alzheimer's disease. Neurobiol Dis 2006; 23:502-11.

22. Glabe CG, Kayed R. Common structure and toxic function of amyloid oligomers implies a common mechanism of pathogenesis. Neurol 2006; 66:S74-8.

23. Glass CK, Saijo K, Winner B, Marchetto MC, Gage FH. Mechanisms underlying inflammation in neurodegeneration. Cell 2010; 140:918-34.

24. Gu X, Greiner ER, Mishra R, Kodali R, Osmand A, Finkbeiner S, Steffan JS, Thompson LM, Wetzel R, Yang XW. Serines 13 and 16 are critical determinants of full-length human mutant huntingtin induced disease pathogenesis in $\mathrm{HD}$ mice. Neuron $2009 ; 64: 828-40$.

25. Hare JF. Intracellular pathways of folded and misfolded amyloid precursor protein degradation. Arch Biochem and Biophys 2006; 451:79-90.
26. Hock C, Konietzko U, Streffer JR, Tracy J, Signorell A, Müller-Tillmanns B, Lemke $U$, Henke K, Moritz E, Garcia E, Wollmer MA, Umbricht D, de Quervain DJ, Hofmann $M$, Maddalena A, Papassotiropoulos A, Nitsch RM. Antibodies against $\beta$-amyloid slow cognitive decline in Alzheimer's disease. Neuron 2003; 38:547-54.

27. Holmes C, Boche D, Wilkinson D, Yadegarfar G, Hopkins V, Bayer A, Jones AB, Bullock B, Love $S$, Neal JW, Zotova E, Nicoll JAR. Long-term effects of $A \beta 1-42$ im munisation in Alzheimer's disease: follow-up of a randomized, placebocontrolled phase I trial. Lancet 2008; 372:216-23.

28. The Huntington's disease collaborative research group. A novel gene containing a trinucleotide repeat that is expanded and unstable on Huntington's disease chromosomes. Cell 1993; 72:971-83.

29. Imarisio S, Carmichael J, Korolchuk V, Chen CW, Saiki S, Rose C, Krishna G, Davies JE, Ttofi E, Underwood BR, Rubinsztein DC. Huntington's disease: from pathology and genetics to potential therapies. J Biochem 2008; 412:191-209.

30. Jackson GR, Sang T, Khoshnan A, Ko J, Patterson $\mathrm{PH}$. Inhibition of mutant huntingtin-induced neurodegeneration In vivo by expression of a polyproline-binding single chain antibody. SFN abstract 2004; 938.5.

31. Kayed R, Head E, Thompson JL, McIntire TM, Milton SC, Cotman CW, Glabe CG. Common structure of soluble amyloid oligomers implies common mechanism of pathogenesis. Science 2003; 300:486-9.

32. Kayed $R$ and Jackson GR. Prefilament tau species as potential targets for immunotherapy for Alzheimer disease and related disorders. Curr Opin Immunol 2009;21:359-63.

33. Khoshnan A, Ko J, Patterson PH. Effects of intracellular expression of anti-huntingtin antibodies of various specificities on mutant huntingtin aggregation and toxicity. Proc Natl Acad Sci USA 2002; 99:1002-7.

34. Khoshnan A, Ko J, Watkin EE, Paige LA, Reinhart PH, Patterson PH. Activation of the IkB kinase complex and nuclear factor- $\mathrm{kB}$ contributes to mutant huntingtin neurotoxicity. $J$ Neurosci 2004; 24:7999-8008.

35. Ko J, Ou S, Patterson PH. New anti-huntingtin monoclonal antibodies: implications for huntingtin conformation and its binding proteins. Brain Res Bull 2001;56:319-29.

36. Kvam E, Nannenga BL, Wang MS, Jia Z, Sierks 
MR, Messer A. Conformational targeting of fibrillar polyglutamine proteins in live cells escalates aggre-gation and cytotoxicity. PLoS One 2009;4:e5727.

37. Lambert MP, Barlow AK, Chromy BA, Edwards C, Freed R, Liosatos M, Morgan TE, Rozovsky I, Trommer B, Viola KL, Wals P, Zhang C, Finch CE, Krafft GA, Klein WL. Diffusible, nonfibrillar ligands derived from $A \beta 1-42$ are potent central nervous system neurotoxins. Proc Natl Acad Sci USA 1998;95: 6448-53.

38. Lansbury PT Jr. Evolution of amyloid: What normal protein folding may tell us about fibrillogenesis and disease. Proc Natl Acad Sci USA 1999; 96:3342-4.

39. Lecerf JM, Shirley $\mathrm{TL}$, Zhu Q, Kazantsev A, Amersdorfer P, Housman DE, Messer A, Huston JS. Human single-chain Fv intrabodies counteract in situ huntingtin aggregation in cellular models of Huntington's disease. Proc Natl Acad Sci USA 2001;8:4764-4769.

40. Lemere CA, Masliah E. Can Alzheimer disease be prevented by amyloid-beta immunotherapy? Nature Rev Neurol 2010; 6:108-19.

41. Levites Y, Jansen K, Smithson LA, Dakin R, Holloway VM, Das P, Golde TE. Intracranial adeno-associated virus-mediated delivery of antipan amyloid $\beta$, amyloid $\beta 40$, and amyloid $\beta 42$ single-chain variable fragments attenuates plaque pathology in amyloid precursor protein mice. $\mathrm{J}$ Neurosci 2006; 26:11923-8.

42. Levites $Y$, Das P, Price RW, Rochette MJ, Kostura LA, McGowan EM, Murphy MP, Golde TE. Anti-A $\beta 42-$ and anti-A $\beta 40$-specific mAbs attenuate amyloid deposition in an Alzheimer disease mouse model. J Clinical Inv 2006; 116:193-201.

43. Liu R, Yuan B, Emadi S, Zameer A, Schulz P, McAllister C, Lyubchenko Y, Goud G, Sierks MR. Single chain variable fragments against $\beta$ Amyloid $(A \beta)$ can inhibit $A \beta$ aggregation and prevent $A \beta$-induced neurotoxicity. Biochemistry 2004; 43: 6959-67.

44. Lo ASY, Zhu Q, Marasco WA. Intracellular antibodies (intrabodies) and their therapeutic potential. Handb Exp Pharmacol 2008;181:34373.

45. Lynch SM, Zhou C, Messer A. An scFv intrabody against the non amyloid component of $\alpha$ synuclein reduces intracellular aggregation and toxicity. J Mol Biol 2008; 377:136-47.

46. Masliah E, Rockenstein E, Adame A, Alford M, Crews L, Hashimoto M, Seubert P, Lee M,
Goldstein J, Chilcote T, Games D, Schenk D. Effects of $\alpha$-synuclein immunization in a mouse model of Parkinson's disease. Neuron 2005;46: 857-68.

47. Miller TW, Shirley TL, Wolfgang WJ, Kang X, Messer A. DNA vaccination against mutant huntingtin ameliorates the HDR6/2 diabetic phenotype. Mol Ther 2003; 7:572-9.

48. Miller TW, Zhou C, Gines S, MacDonald ME, Mazarakis ND, Bates GP, Huston JS, Messer A. A human single-chain Fv intrabody preferentially targets amino-terminal Huntingtin's fragments in striatal models of Huntington's disease. Neurobiol Dis 2005;19:47-56.

49. Murphy RC, Messer A. A single-chain Fv intrabody provides functional protection against the effects of mutant protein in an organotypic slice culture model of Huntington's disease. Mol Brain Res 2004;121:141-5.

50. Nakamura KK, Aminoff MJMJ. Huntington's disease: clinical characteristics, pathogenesis and therapies. Drugs Today 2007; 4397-116.

51. Nannenga BL, Zameer A, Sierks MR. Antioligomeric single chain variable domain antibody differentially affects huntingtin and $\alpha$-synuclein aggregates. FEBS Letters 2008; 582:517-522.

52. Oddo S, Billings L, Kessiak JP, Cribbs DH, LaFerla FM. Immunotherapy leads to early, but not late, hyperphosphorylated tau aggregates via the proteosome. Neuron 2004;43:321-32.

53. Paganetti $P$, Calanca V, Galli C, Stefani $M$, Molinari M. $\beta$-site specific intrabodies to decrease and prevent generation of Alzheimer's $A \beta$ peptide. J Cell Biol 2005; 168:863-8.

54. Papachroni KK, Ninkina N, Papapanagiotou A, Hadjigeorgiou GM, Xironerisiou G, Papadimitriou A, Kafofoutis A, Buchman VL. Autoantibodies to alpha-synuclein in inherited Parkinson's disease. J Neurochem 2007;101:74956.

55. Passani LA, Bedford MT, Faber PW, McGinnis KM, Sharp AH, Gusella JF, Vonsattel J-P, MacDonald ME. Huntingtin's WW domain partners in Huntington's disease post-mortem brain fulfill genetic criteria for direct involvement in Huntington's disease pathogenesis. Hum Mol Genet 2000;9:2175-2182.

56. Peters MF, Nucifora FC, Kushi J, Seaman HC, Cooper JK, Herring WJ, Dawson VL, Dawson TM, Ross CA. Nuclear targeting of mutant huntingtin increases toxicity. Mol Cell Neurosci 1999;14:121-128.

57. Pettersen EF, Goddard TD, Huang CC, Couch GS, 
(ireenblall IDM, Meng liC, lierrin TE. UCSF ('ilinown $n$ visunlizantion system for exploratory reman' ind und mulysis. J Comput Chem 2004;25: $100,9=12$.

36. U, In Z,all, Wang Y, Sapp E, Cuiffo B, Wanker E, Iluyden MR, Kegel KB, Aronin N, DiFiglia M. Ilunllngtin bodies sequester vesicle-associated proleins hy a polyproline-dependent interaction. $\mathrm{J}$ Neurrosci 2004; 24:269-81.

51). Rangan SK, Liu R, Brune D, Planque S, Paul S, Sicrks MR. Degradation of $\beta$-amyloid by protcolytic antibody light chains. Biochemistry 2003;42:14328-34.

6). Relkin NR, Szabo P, Adamiak B, Burgut, Monthe C, Lent RW, Younkin S, Younkin L, Schiff R Weksler ME. 18-Month study of intravenous immunoglobulin for treatment of mild Alzheimer disease. Neurobiol Aging 2009;30:1728-36.

61. Reynolds AD, Stone DK, Hutter JAL, Benner EJ, Mosley RL, Gendelman HE. Regulatory $T$ cells attenuate neurodegeneration in a model of Parkinson's disease. J Immunol 2010; 184:2261-71.

62. Rockabrand E, Slepko N, Pantalone A, Nukala VN, Kazantsev A, Marsh JL, Sullivan PG, Steffan JS, Sensi SL, Thompson LM. The first 17 amino acids of Huntingtin modulate its sub-cellular localization, aggregation and effects on calcium homeostasis. Hum Mol Genet 2007;16:61-77.

63. Rosenmann $\mathrm{H}$, Grigoriadis $\mathrm{N}$, Karussis D, Boimel $\mathrm{M}$, Touloumi O, Ovadia $\mathrm{H}$, Abramsky $\mathrm{O}$. Tauopathy-like abnormalities and neurologic deficits in mice immunized with neuronal tau protein. Arch Neurol 2006;63:1459-67.

64. Satloway S, Sperling R, Gilman S, Fox NC, Blennow K, Raskind M, Sabbagh M, Honig LS, Doody R, van Dyck CH, Mulnard R, Barakos J, Gregg KM, Liu E, Lieberburg I, Schenk D, Black $\mathrm{R}$, Grundman M; Bapineuzumab 201 Clinical Trial Investigators. A phase 2 multiple ascending dose trial of bapineuzumab in mild to moderate Alzheimer disease. Neurol 2009;73:2061-70.

65. Schenk D, Barbour R, Dunn W, Gordon G, Grajeda H, Guido T, Hu K, Huang J, JohnsonWood K, Khan K, Kholodenko D, Lee M, Liao Z, Lieberburg I, Motter R, Mutter L, Soriano F, Sh.spp G, Vasquez N, Vandevert C, Walker S, Wogulis M, Yednock T, Games D, Seubert P. Immunization with amyoid-beta attenuates Alzheimer disease-like pathology in the PDAPP mouse. Nature 1999; 400:173-7.

66. Schwartz M, Shechter R. Protective autoimmunity functions by intracranial immunosurveillance to support the mind: The missing link between health and disease. Molec Pyschiat 2010; 15:342-54.

67. Slow EJ, Graham RK, Osmand AP, Devon RS, Lu G, Deng Y, Pearson J, Vaid K, Bissada N, Wetzel R, Leavitt BR, Hayden MR. Absence of behavioral abnormalities and neurodegeneration in vivo despite widespread neuronal huntingtin inclusions. Proc Natl Acad Sci USA 2005;102:11402-7.

68. Small SA, Duff $K$. Linking $A \beta$ and tau in lateonset Alzheimer's disease: a dual pathway hypothesis. Neuron 2008; 60:534-42.

69. Solomon B, Koppel R, Hanan E, Katzav T. Monoclonal antibodies inhibit in vitro firbrillar aggregation of the Alzheimer $\beta$-amyloid peptide. Proc Natl Acad Sci USA 1996;93:452-5.

70. Solomon B, Koppel R, Frenkel D, Hanan-Aharon E. Disaggregation of Alzheimer $\beta$-amyloid by site-directed mAb. Proc Natl Acad Sci USA 1997;94: 4109-12.

71. Southwell AL, Khoshnan A, Dunn DE, Bugg CW, Lo DC, Patterson PH. Intrabodies binding the proline-rich domains of mutant huntingtin increase its turnover and reduce neurotoxicity. $\mathrm{J}$ Neurosci 2008;28:9013-20.

72. Southwell AL, Ko J, Patterson PH. Intrabody gene therapy ameliorates motor, cognitive, and neuropathological symptoms in multiple mouse models of Huntington's disease. J Neurosci 2009;29:13589-602.

73. Steffan JS, Kazantsev A, Spasic-Boskovic O, Greenwald M, Zhu Y-Z, Gohler H, Wanker EE, Bates GP, Housman DE, Thompson LM. The Huntington's disease protein interacts with p53 and CREB-binding protein and represses transcription. Proc Natl Acad Sci USA 2000;97:6763-8.

74. Sudol KL, Mastrangelo MA, Narrow WC, Frazer ME, Levites YR, Golde TE, Federoff HJ, Bowers WJ. Generating differentially targeted amyloid-l. specific intrabodies as a passive vaccination strategy for Alzheimer's disease. Mol Ther 2009; 17:2031-40.

75. Teitelbaum D, Aharoni R, Sela M, Arnon R. Cross-reactions and specificities of monoclonal antibodies against myelin basic protein and against the synthetic copolymer 1. Proc Natl Acad Sci USA. 1991;88: 9528-32.

76. Thakur AK, Jayaraman M, Mishra R, Thakur M, Chellgren VM, L Byeon I-J, Anjum DH, Kodali $\mathrm{R}$, Creamer TP, Conway JF, M Gronenborn A, Wetzel R. Polyglutamine disruption of the huntingtin exon $1 \mathrm{~N}$ terminus triggers a complex aggregation mechanism. Nat Struct Mol Biol $2009 ; 16: 380-9$. 
77. Thompson LM, Aiken CT, Kaltenbach LS, Agrawal N, Illes $\mathrm{K}$, Khoshnan A, MartinezVincente M, Arrasate M, O'Rourke JG, Khashwji H, Lukacsovich T, Zhu Y-Z, Lau AL, Massey A, Hayden MR, Zeitlin SO, Finkbeiner S, Green KN, LaFerla FM, Bates G, Huang L, Patterson PH, Lo DC, Cuervo AM, Marsh JL, Steffan JS. IKK phosphorylates huntingtin and targets it for degradation by the proteasome and lysosome. J Cell Biol 2009;187:1083-99.

78. Vellas B, Black R, Thal LJ, Fox NC, Daniels M, MrLennan G, Tompkins C, Leibman C, Pomfret M, Grundman M; AN1792 (QS-21)-251 Study Team. Long-term follow-up of patients immunized with AN1792: reduced functional decline in antibody responders. Curr Alzheimer Res 2009; 6: 144-51.

79. Wang C-E, Zhou H, McGuire JR, Cerullo V, Lee
B, Li S-H, Li X-J. Suppression of neuropil aggregates and neurological symptoms by an intracellular antibody implicates the cytoplasmic toxicity of mutant huntingtin. J Cell Biol 2008; 181:803-16.

80. Wolfgang WJ, Miller TW, Webster JM, Huston JS, Thompson LM, Marsh JL, Messer A. Suppression of Huntington's disease pathology in Drosophila by human single-chain Fv antibodies. Proc Natl Acad Sci USA 2005;102:11563-8.

81. Yuan B, Sierks MR. Intracellular targeting and clearance of oligomeric $\square$-synuclein alleviates toxicity in mammalian cells. Neurosci Lett 2009; 459:16-18.

82. Zhou C, Emadi S, Sierks MR, Messer A. A human single-chain $\mathrm{Fv}$ intrabody blocks aberrant cellular effects of overexpressed alpha-synuclein. Mol Ther 2004; 10:1023-31. 